U. S. DEPARTMENT OF COMMERCE BUREAU OF STANDARDS

\title{
RED CEDAR SHINGLES
}

COMMERCIAL STANDARD CS31-31

A RECORDED STANDARD OF THE INDUSTRY 
Below are described some of the series of publications of the Department of Commerce which deal with various phases of waste elimination.

\section{Simplified Practice Recommendations.}

These present in detail the development of programs to eliminate unnecessary variety in sizes, dimensions, styles, and types of over 120 commodities. They also contain lists of associations and individuals who have indicated their intention to adhere to the recommendations. These simplified schedules, as formulated and approved by the industries, are indorsed by the Department of Commerce.

\section{American Marine Standards.}

These are promulgated by the American Marine Standards Committee, which is controlled by the marine industry and administered as a unit of the division of simplified practice. Their object is to promote economy in construction, equipment, maintenance, and operation of ships. In general, they provide for simplification and improvement of design, interchangeability of parts, and minimum requisites of quality for efficient and safe operation.

\section{Commercial Standards.}

These are developed by various industries under a procedure similar to that of simplified practice recommendations. They are, however, primarily concerned with considerations of grade, quality, and such other characteristics as are outside the scope of dimensional simplification.

Lists of the publications in each of the above series can be obtained by applying to the Bureau of Standards, Washington, D. C. 


\title{
U. S. DEPARTMENT OF COMMERCE \\ R. P. LAMONT, Secretary \\ BUREAU OF STANDARDS \\ GEORGE K. BURGESS, Director
}

\section{RED CEDAR SHINGLES}

\section{COMMERCIAL STANDARD CS31-31}

\author{
[Issued November 23, 1931]
}

Effective date for New Production July 1, 1931

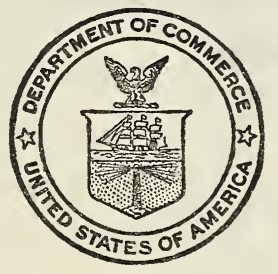

UNITED STATES

GOVERNMENT PRINTING OFFICE

WASHINGTON : 1931

For sale by the Superintendent of Documents, Washington, D. C. - - Price 10 cents 


\section{CONTENTS}

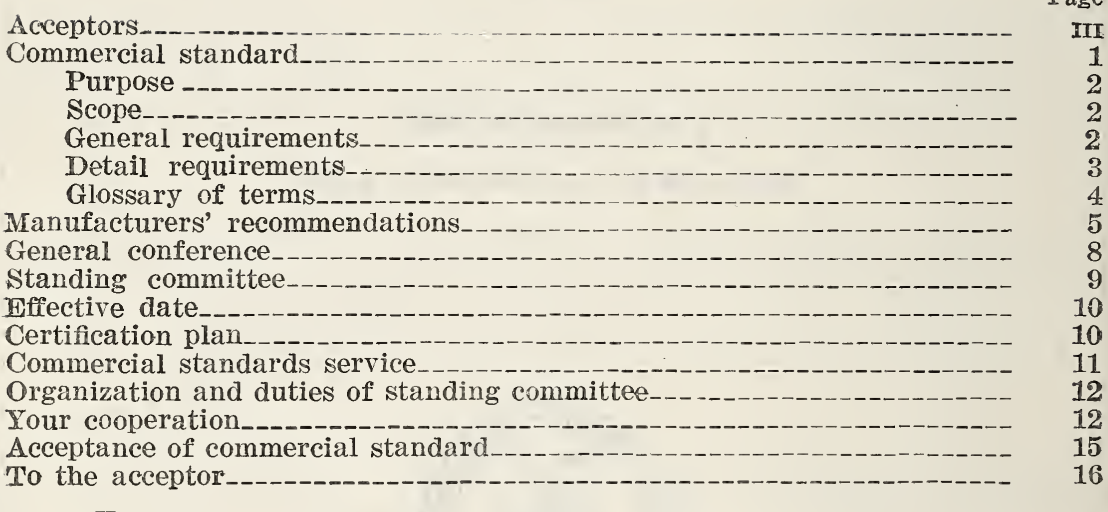




\section{ASSOCIATIONS}

American Institute of Architects, Florida central chapter, St. Petersburg, Fla. (in principle).

American Specification Institute, Chicago, Ill.

Associated General Contractors of America (Inc.), Bridgeport chapter, Bridgeport, Conn.

Associated General Contractors of America (Inc.), Portland chapter, Portland, Oreg.

Associated General Contractors of America (Inc.), San Diego chapter, San Diego, Calif.

California Retail Lumber Dealers Association, Garden Grove, Calif.

Carolina Retail Lumber \& Building Supply Association, Charlotte, N. C.

Cedar Manuiacturers Association, Seattle, Wash. (in principle).

Illinois Lumber \& Material Dealers Association, Chicago, Ill.

Kentucky Retail Lumber Dealers Association, Louisville, $\mathrm{Ky}$.

Lumbermen's Association of Texas, Houston, Tex.

Lumbermen's Exchange of the City of Philadelphia, The, Philadelphia, Pa.

Lumbermen's Service Association, Los Angeles, Calif.

Michigan Retail Lumber Dealers' Association, Lansing, Mich.

Mountain States Lumber Dealers Association, The, Denver, Colo.

National Association of Builders Exchanges, Washington, D. C.

National Lumber Distributors (Ltd.), Vancouver, British Columbia.

National Lumber Manufacturers Association, Washington, D. C.

National Retail Lumber Dealers' Association, Chicago, Ill.

Nebraska Lumber Merchants Association, Lincoln, Nebr.

Northeastern Retail Lumbermen's Association, Rochester, N. Y.

Red Cedar Shingle Bureau, Seattle, Wash.

Retail Lumber Dealer's Association of Indiana, Crown Point, Ind.

United Roofing Contractors' Association, Chicago, Ill. (in principle).

Washington \& Oregon Shingle Association, Seattle, Wash.

West Coast Lumbermen's Association, Seattle, Wash. (in principle).

Western Retail Lumbermen's Association, Spokane, Wash.

Wisconsin Retail Lumbermen's Association, Milwaukee, Wis.
FTRMS

A One Building Material Co., Evansville, Ind.

Acme Steel Co., Chicago, Ill.

Acme Steel Co., Seattle, Wash. (in principle).

Alberg \& Barron Shingle Co., Port Angeles, Wash.

Alberni Pacific Lumber Co. (Ltd.), Port Alberni, British Columbia.

Alexander Lumber Co., Chicago, Ill.

Allan \& Wallace, Omaha, Nebr.

Aloha Lumber Co., Aloha, Wash.

American Lumberman, Seattle, Wash. (in principle).

Anderson Lumber Co., Ogden, Utah.

Angelina County Lumber Co., Keltys, Tex. (in principle).

Arkansas Valley Lumber Co., The, Wichita, Kans.

Arlington Mill Co., Arlington, Wash.

Arrington \& Co., W. C. (Inc.), Norfolk, Va.

Alt Stained Shingle Co. (Inc.), Buffalo, N. Y.

Ashton \& Evans, Salt Lake City, Utah. Aubur'n Lumber Co., Auburn, Calif.

Baker, Vogel \& Roush, Seattle, Wash. (in principle).

Bald Mountain Mill Co., Mount Vernon, Wash.

Baldridge Lumber Co., J. C., Albuquerque, N. Mex.

Barr Lumber Co., Santa Ana, Calif. Baxter, C. B., Kansas City, Mo.

Baxter Lumber \& Mercantile Co., Pittsburg, Kans.

Beaver Falls Planing Mill Co., Beaver Falls, Pa.

Beckwith Lumber Co., H. E., Chetek, Wis.

Bennett Lumber Co., Kansas City, Mo. Blackburn, Robert, Milwaukee, Wis.

Black Mountain Lumber Co., Black Mountain, N. C.

Blackstock Lumber Co., Seattle, Wash. Bloedel, Stewart \& Welch Co. (Ltd.), Vancouver, British Columbia.

Blue Ribbon Products Co., Kalama, Wash.

Booth \& Boyd Lumber Co., Saginaw, Mich.

Borden Guiney \& Kendall Co., Fall River, Mass.

Bratlie Bros. Mill Co., Ridgefield, Wash.

Brattin \& Son, F. J., Shepherd, Mich.

Braun, Ray Bros. \& Finley Co., Omaha, Nebr.

Brey-Wright Lumber Co., Porterville, Calif. 
Bridgeport Shingle Co. (Ltd.), Eburne P. O., British Columbia.

Brightbill, J. M. (Inc.), Hummelstown, Pa.

British Columbia Lumber \& Shingle Manufacturers (Ltd.), Vancouver, British Columbia (in principle).

British Columba Red Cedar Shingle Co. (Ltd.), Vancouver, British Columbia.

Bronson Lumber Co., C. C., Seattle, Wash.

Brown Lumber Co., Dan (Inc.), Anderson, S. C.

Brunette Operations, New Westminster, S. C.

Buell, Benning C., Buffalo, N. Y.

Burns Shingle Co., Anacortes, Wash.

Burritt Co., The A. W., Bridgeport, Conn.

Burrow Lumber Co., Canyon, Tex.

Bush \& Miller, Vancouver, British Columbia.

Cabot, Samuel (Inc.), Boston, Mass.

Cameron \& Co., William (Inc.), Waco, Tex.

Campbell Lumber \& Manufacturing Co., The, Toledo, Ohio.

Canadian Puget Sound Lumber \& Timber Co. (Itd.), Victoria, British Columbia.

Canadian Western Lumber Co. (Lit.), Fraser Mills, British Columbia.

Capilano Timber Co. (Ltd.), North Vancouver, British Columbia.

Carbon River Shingle Co., Fairfaz, Wash.

Carhart Lumber Co., Wayne, Nebr.

Carpenter Lumber Co., W. I., Everett, Wash.

Case Cedar \& Shingle Co., Raymond, Wash.

C. B. Lumber \& Shingle Co., Everett, Wash.

Central Lumber Co., Stillwater, Minn.

Central Warehouse Iumber Co., Minneapolis, Minn.

Certain Lumber Co., W. N., Neodesha, Kans.

Chapel Co., Linn S. (Inc.), Elmira, N. $Y$.

Chapin Lumber Co., The, Aurora, Colo. Chapman Lumber Co., C. W., Waterloo, Iowa.

Charleston Lumber Co., The, Charleston, W. Va.

Chase Lumber \& Coal Co., Payson, Utah.

Chew Shingle Co., Joseph (Ltd.), Vancouver, British Columbia.

Citizens Lumber Co., Sturgis, Mich.

Clark County Lumber Co., The, Springfield, Ohio.

Clear Lake Shingle Co., Clear Lake, Wash.

Coast Cedar Shingle Co., Seattle, Wash.
Cockfield, Brown \& Co. (Ltd.), Vancouver, British Columbia (in principle).

Columbia Lumber Co., Seattle, Wash.

Connellsville Construction Co., Connellsville, Pa.

Conover Lumber Co., Keyport, N. J.

Coral Gables Lumber \& Supply Co., Coral Gables, Fla.

Corwin Lumber Co., The, Jackson, Mich.

Costello Lumber Co., James, Liberty, Mo.

Cragin \& Son (Inc.), Midland, Tex.

Creith-Potter Lumber Co., The, Columbus, Ohio.

Creo-Dipt Co. (Inc.), North Tonawanda, N. Y.

Crescent Logging Co., Port Angcles, Wash.

Crescent Shingle Co., Kelso, Wash.

Cumberland Shingle Co., Hamilton, Wash.

Davenport, Peters Co., Boston, Mass.

Davis Lumber Co., Henry D., Portland, Oreg.

Dekle Lumber Co., Jacksonville, Fla. (in principle).

Dickerson Lumber Co., Huntington, W. Va.

Dillard \& Phillips, Concrete, Wash.

Dix Lumber Co., North Cambridge, Mass.

Dodds Lumber Co., Omaha, Nebr.

DuPlain Lumber Co., Joseph A., Rockford, 111.

Duracolor Corporation, North Tonawanda, N. X.

Eastern Railway \& Lumber Co., Centralia, Wash.

East Hoquiam Shingle Co., Hoquiam, Wash.

Edham Co. (Inc.), The, St. Paul, Minn. Evans \& Callaway, Fowler, Ind.

Everett Lumber \& Shingle Co., Everett, Wash.

Exchange Lumber Co., Roanoke, Va. Eyre Shingle Co., Arlington, Wash.

Fanny Bay Shingle Co. (Ltd.), Fanny Bay, British Columbia.

Farmers' Lumber Co., Nashua, Mont. Fitite Cedar Shake Co., Seattle, Wash.

Fluhrer Bros. (Inc.), Mayger, Oreg.

I'rey Planing Mill Co., The, Louisville, Ky.

Garden Grove Lumber \& Cement Co., Garden Grove, Calif.

Garrison Lumber Co., L. D., Corpus Christi, Tex.

Grayling Box Co., Grayling, Mich.

Gray Lumber \& Shingle Co., Seattle, Wash.

Gray Shingle Co., Robert, Hoquiam, Wash.

Grays Harbor Sales Corporation, Hoquiam, Wash. 
Great Northern Lumber Co., Wenatchee, Wash.

Green, Jesse W., Birmingham, Ala.

Green Mill Co., Quilcene, Wash.

Gulf Manufacturing \& Lumber Co., Beaumont, Tex.

Hammond Cedar Co. (Ltd.), New Westminster, British Columbia.

Fammond Lumber Co., Los Angeles, Calif.

Hammoud Lumber Co., Portland, Oreg.

Hanbury \& Co., J. (Ltd.), Vancouver, British Columbia.

Hartford Lumber Co., The, Hartford, Conn.

Hartwick Woodfield Co., Jackson, Mich.

Harvard Lumber Co., The, Cleveland, Ohio.

Hawkeye Lumber \& Coal Co., The, Cedar Rapids, Iowa.

Heath Lumber \& Shingle Co., Granite Falls, Wash.

Heitmann Lumber Co., Chicago, IIl.

Heyer Sons, W. H., Sumner, Iowa.

Hill Mill Co., Fairfax, Wash.

Hinkle Lumber Co., Paris, Tex.

Hoffman \& Baldwin, West Chester, Pa.

Hoo Hoo Club of St. Louis No. 6, St. Louis, Mo. (in principle).

Horne Bros. Shingle Co. (Ltd.), North Vancouver, British Columbia.

Houston Lumber Co., The A. C., Wichita, Kans.

Hoyt, J. M., Sedro Woolley, Wash.

Hulbert Mill Co., William, Everett, Wash.

Huntington Shingle Co., Mapleton, Oreg.

Huntting Merritt Lumber Co. (Ltd.), Vancouver, British Columbia.

Index Cedar Products Co., Index, Wash.

Ingram, W. F. (Inc.), Kalama, Wash.

Inspected Shingles (Ltd.), North Vancouver, British Columbia.

Interstate Lumber Co., Missoula, Iont.

Iowa Builders Supply Co., Cedar Rapids, Iowa.

Island Mill Lumber Co., Alpena, Mich. Jackson \& Tindle (Inc.), Grand Rapids, Mich.

Jamison Lumber \& Shingle Co., Everett, Wash.

Jamison Lumber \& Shingle Co., Kansas City, Mo.

Jerns Manufacturing Co., N., Bellingham, Wash.

Jeter Lumber Co., Cameron, Tex.

Johnston-McGraw Shingle Co., Vernonia, Oreg.

Kerriston Shingle Co., Kerriston, Wash

Kirkpatrick, Thomas, Vancouver, British Columbia.
Kratz, Shingle Co., Henry (Inc.), Clatskanie, Oreg.

Krause \& Managan (Inc), Lake Charles, La.

I a Crosse Lumber Co., Louisiana, Mo.

La Junta Trading Co., La Junta, Colo.

Lake Sammamish Shingle Co., Redmond, Wash.

Lambert Lumber Co., Leavenworth, Kans.

Lander Lumber Co., El Paso, Tex.

Lane Lumber Corporation, Arthur E., New York, N. Y.

Law, Law \& Potter, Madison, Wis.

Leybold-Smith Shingle Co., Tacoma, Wash.

Lewis Shingle Co., J. A., South Bend, Wash.

Little, W. A., Washington, Pa.

Long-Bell Lumber Sales Corporation, Longview, Wash.

Lovell-Scholfield Lumber Co., The, Eldora, Iowa.

Lowell-Whipple Co., The, IVorcester, Mass.

Lumberman's Club of Arizona, Phoenix, Ariz.

Lyman-Hawkins Lumber Co., The, Akron, Ohio.

Lyman Lumber Co., Lyman, Wyo.

Mackie Mill Co., Markham, Wash.

Madison Lumber \& Mill Co., Lewiston, Idaho.

Massar Lumber Co., Monnt Vernon, Wash.

Mauk Lumber Co., The C. A., Toledo, Ohio.

Mauk Seattle Lumber Co., Seattle, Wash.

McCarter Shingle Co. (Ltd.), Victoria, British Columbia.

McCoy-Kelly Co., Bellingham, Wash.

McFarland Lumber \& Hardware Co., Salt Lake City, Utah.

McMann, J. J., Wakeman, Ohio.

McMaster-Horton Cedar Manufacturing Co. (Ltd.), Victoria, British Columbia.

McMaster Shingle Co., John, Marys. ville, Wash.

McNair Shingle Co. (Ltd.), Robert, Vancouver, British Columbia.

Merced Lumber Co., Merced, Calif.

Merrell Lumber \& Hardware Co., Brigham City, Utah.

Merrill \& Ring Lumber Co., Seattle, Wash.

Mershon Lumber Co., John D., Sayinaw, Mich.

Midwest Lumber Co., Dubuque, Iowa.

Miles Lumber \& Coal Co., A. W., Livingston, Mont.

Miller \& Yeager, Terre Haute, Ind.

Miller Cedar Lumber Co., E. C., Aberdeen, Wash.

Milligan Co., D., Jefferson, Iowa. 
Milwaukie Lumber \& Shingle Co., Milwaukie, Oreg.

Mitchell Lumber" \& Supply Co., Wilkinsburg, Pa.

Monarch Mill Co., Everett, Wash.

Moore \& Moore (Inc.), Mason City, Iowa.

Moore \& Williams, Jacksonville, Fla.

Morrison, Gay, Beaumont, Tex.

Morrison-Merrill \& Co., Salt Lake City, Utah.

Motor Mill Co., Seattle, Wash.

Nelson, W. F., Dallas, Tex.

Nettleton Lumber Co., Seattle, Wash.

New England Manufacturing Co., Everett, Wash.

Northern Lumber Co., Estherville, Iowa.

North Hudson Manufacturing Co. North Bergen, N. J.

North Lumber \& Manufacturing Co., Kalamazoo, Mich.

North Western Lumber Co., Hoquiam, Wash.

Norton \& Son, I. S., Algona, Iowa.

Olympia Shingle Co., The, Olympia, Wash.

Oregon Shingle Co., Portland, Oreg.

Pacific National Lumber Co., Tacoma, Wash.

Pacific Shingle Co., The (Lta.), Coquitlam, British Columbia.

Pacific Stained Shingles (Inc.), Seattle, Wash.

Pacific States Lumber Co., Tacoma, Wash.

Palburn (Inc.), Buffalo, N. Y.

Patton Timber Co., Ashland, Ky.

Perma Stain Co., The, Cleveland, Ohio.

Polson Lumber \& Shingle Co., Hoquiam, Wash.

Porter Lumber Co., The, Springfield, III.

Prosperity Shingle Co. (Ltd.), North Vancouver, British Columbia.

Proudfit Lumber Co., P. P., Chadron, Nebr.

Putnam \& Jones, Carthage, Mo.

Putnam \& Jones, Oklahoma City, Okla.

Quality Shingle Co. (Inc.), Edmonds, Wash.

Reed Mill Co., Shelton, Wash.

Risser Lumber Co., Art, Paris, Ill.

Riverside Lumber Co., Knoxville, Tenn.

Rockford Lumber \& Fuel Co., Rockford, Ill.

Roles Bros. Shingle Co., Linnton, Oreg.

Root, C. D., Crown Point, Ind.

Royal Shingle Co., Whites, Wash.

Saginaw Shingle Co. (Inc.), Blaine, Wash.

Saginaw Timber Co., Aberdeen, Wash.

St. Louis Lumber Co., St. Louis, Mo.

St. Paul \& Tacoma Lumber Co., Tacoma, Wash.

Seattle Cedar Lumber Manufacturing Co., Seattle, Wash.
Shelton Mason County Commercial Club, Shelton, Wash. (in principle).

Siemons Lumber Co., Bellingham, Wash.

Simpson Logging Co., Shelton, Wash. Sinclair Lumber \& Fuel Co., Grand Rapids, Mich.

Sitterding-Carneal-Davis Co. (Ine.), Richmond, Va.

Skagit Mill Co., Lyman, Wash.

Smith \& Co., T. H., Salt Lake City, Utah.

Smith Lumber \& Shingle Co., M. R., Seattle, Wash.

Sneed-McGinnes Lumber Co., Lakeland, Fla.

Snider Shingle Co., Carlton, Oreg.

Snohomish County Forum, Granite Falls, Wash. (in principle).

Snoqualmie Falls Lumber Co., Snoqualmie Falls, Wash.

Solie Lumber Co., Janesville, Wis.

Sones Lumber Co., El Centro, Calif.

Soule Shingle Co, Stearnsville, Wash.

Sound Timber Co., The, Seattle, Wash. (in principle).

South Park Lumber Co., St. Joseph, Mo.

South Sidc Lumber \& Supply Co., The, Toleds, Ohio.

Sowers-Benbow Lumber Co., The, Columbus, Ohio.

Spahn \& Rose Lumber Co., Dubuque, Iowa.

Spaulding Logging Co., Chas. K., Portland, Oreg.

Spencer-Sauer Lumber Co., Houston, Tex.

Spolzane Hoo Hoo Club, Spokane, Wash. (in principle).

Standard Stained Shingle Co., Rock Island, Ill.

Stanton Lumber Co., Stanton, Calif.

Star Lumber Co., The, Liberal, Kans. Sterling Lumber Co. (Ltd.), Vancouver, British Columbia.

Stevenson Co., The J. E., Trenton, N. J. Stewart Lumber Co., A. P., Thermopolis, Wyo.

Stoltze Manufacturing Co. (Ltd.), Vancouver, British Columbia.

Super Shingle Co., The, Everett, Wash. Sweet Catalogue Service, New York, N. Y. (in principle).

Temple Lumber Co., Houston, Tex.

Tenino Shingle Co., Tenino, Wash.

Thompson Lumber Co., Minneapolis, Minn.

Thurston-Flavelle (Ltd.), Port Moody, British Columbia.

Todd Lumber Co., R. H., Ocala, Fla.

Tolles \& Co., J. H., Nashua, N. H.

Tuttle Bros., Westfield, N. J.

United Mills (Ltd.), New Westminster, British Columbia.

University of Washington, Seattle, Wash. (in principle). 
Updike-Kennedy Co. (Inc.), Trenton, N. J.

Valley Lumber Co., Fresno, Calif.

Varner Bros., Dallas, Tex.

Velde Lumber Co., Pekin, Ill.

Vickere Lumber Co., T. W., Sheridan, Wyo.

Victoria Lumber \& Manufacturing Co. (Ltd.), Chemainus, British Columbia.

Voorhees Lumber Co., Flora, Ind.

Wade-Talcott Lumber Co., Tulsa, Okla.

Wagner Lumber Co., Monroe, Wash.

Wallace Lumber \& Manufacturing Co., Sultan, Wash.

Wartes Roof \& Service Co., Seattle, Wash.

Wasser-Hubbard Mill Co., Dryad, Wash.

Wayland Mill Co., Seattle, Wash.

IVearn Lumber Co., J. H., Charlotte, N. C.

Weatherbest Stained Shingle Co. (Inc.), North Tonawanda, N. Y.

Wenthe Bros. Co., Effingham, Ill.

Western Lumber Co. of San Diego, San Diego, Calif.

Weyerhaeuser Timber Co., Everett, Wash. (in principle).

Weyerhaeuser Timber Co., Tacoma, Wash.

Whatcom Falls Mill Co., Bellingham, Wash.
Wheelwright Lumber Co., Ogden, Utah.

White Lumber Co., The R. B., Granville, Ohio.

White River Lumber Co., Enumclaw, Wash.

White River Lumber Co., Meeker, Colo.

Wilbur Lumber Co., West Allis, Wis. Willamette Valley Lumber Co., Dallas, Oreg.

Willapa Harbor Lumber Mills, Raymond, Wash.

Willapa Lumber Co., Raymond, Wash.

Wisconsin's Transfer Yard, Oshkosh, Wis.

Wolverine Creosoted Products Co., Detroit, Mich.

Wood \& Iverson (Inc.), Hobart, Wash.

Wood \& Son, Edward J., Clarksburg, W. Va.

Woodbridge Lumber Co., Woodbridge, N. J.

Woodlawn Mill Co., Hoquiam, Wash. Wyman Lumber Co., M. A., Seattle, Wash.

\section{GOVERNMENT}

Treasury Department, Washington, D. C.

Veterans' Administration, Washington, D. C. 



\section{RED CEDAR SEINGLES}

\section{COMIERCIAL STANDARD CS31-31}

On March 27, 1931, a general conference of representative manufacturers, distributors, and users of red cedar shingles adopted a commercial standard for this commodity. The industry has since accepted and approved for promulgation by the Department of Commerce, through the Bureau of Standards, the conmercial standard as shown herein.

The standard became effective for new production on July 1 , 1931.

Promulgation recommended.

Promulgated.

Aproven.

$$
\text { Chief, Division of Trade Standards. }
$$

George K. Burgess, Director, Bureau of Standards.

R. P. LAMont, Secretary of Commerce.

$76288^{\circ}-31-2$ 


\title{
COMMERCIAL STANDARD CS31-31
}

\author{
PURPOSE
}

This quality standard for western red cedar ${ }^{1}$ shingles is a basis for common understanding between manufacturers, distributors, and users of this product. By its general acceptance, use, and certification by labels, it is hoped that interest may be increased in the manufacture, sale, and use of high-grade wood shingles which should redound to the mutual advantage of all concerned.

The protection and service afforded by wood shingles and, consequently, the success of the industry, is in direct proportion to the quality of shingles used and, therefore, the following commercial standard of quality is provided for guidance in the manufacture, sale, and use of this product.

\section{SCOPE}

This quality standard provides a minimum specification for the highest commercial grade of western red cedar shingles known as grade A in American Lumber Standards and as published in Simplified Practice Recommendation No. 16. It covers length, width, thickness, grain, defects, color, packing, and the grading tolerances for these requirements.

\section{GENERAL REQUIREMENTS}

All commercial standard red cedar shingles shall be of 100 per cent heartwood, well manufactured and neatly packed; they must comply with or exceed the specifications herein established for quality.

Grain.-All commercial standard shingles shall be strictly edge grained; that is, the thin lines constituting the annual or growth rings shall be vertical when the shingle is laid flat as in use. Edge grain is synonomous with quartered or quarter-sawed lumber or flooring and the condition is considered fulfilled when no portion of the grain slope exceeds $45^{\circ}$ from the perpendicular.

Defects.-Knots, worm holes, decay, shakes, checks, crimps, flatgrain, cross grain, and sapwood constitute natural defects that are not admissable, nor are defects in manufacturing, including shims, feather tips, diagonal grain, waves, and torn fiber.

Cotor--Variations in the color of heartwood of western red cedar are caused by differences in the density of natural color filtrations. Conclusive research has indicated no difference in the strength or durability of wood of varying color and consequently color differences are not considered defects.

1 Western red cedar (Thuja plicata), a species of tree whose chief commercial range is in Oregon. Washington, and British Columbia. Its enormous size and even-textured. easily workable wood, together with its resistance to decay make it especially adaptable for roofing shingles. 
Length.-Minimum length shall be 16 inches. The usual lengths in addition to 16-inch shingles are 18 and 24 inches.

A minus tolerance of 1 inch will be allowed in not more than 10 per cent of any shipment. Shingles cut from equalized blocks $\mathrm{or}^{\circ}$ rebutted may be $1 / 4$ inch less than the standard length.

Width.-Maximum width shall be 14 inches. Minimum width for shingles 16 inches up to not including 24 inches long, shall be 3 inches. Minimum width for shingles 24 inches and longer shall be 4 inches. In 16 and 18 inch shingles those less than 4 inches in width shall not constitute more than 10 per cent of any shipment.

Shingles shall be uniform in width; that is, possessing parallel sides. A tolerance of $1 / 4$ inch variation in the width shall be allowed.

Thickness.-Shingles are measured for thickness at the butt ends and designated according to the number of pieces necessary to constitute a specific unit of thickness. For example $4 / 2$ indicates that 4 shingles measure 2 inches, while $5 / 21 / 4$ means that each 5 shingles measure $21 / 4$ inches in thickness.

Shingles shall be uniform in thickness, but a minus tolerance of 3 per cent is allowable to compensate for the difference in shrinkage encountered in kiln drying. This tolerance is based on the total thickness of the bundle.

Packing.-All shingles shall be packed flat in straight courses and the unit shall be the "square" pack ${ }^{2}$ and shall contain not less than the minimum quantity specified in the following table:

TABd 1.-Running inches per bundle and unit for standard packing

\begin{tabular}{|c|c|c|c|c|c|c|c|}
\hline $\begin{array}{c}\text { Length } \\
\text { ?(in } \\
\text { inches) }\end{array}$ & $\begin{array}{l}\text { Thickness } \\
\text { (in inches) }\end{array}$ & $\begin{array}{l}\text { Number } \\
\text { courses } \\
\text { per } \\
\text { bundle }\end{array}$ & $\begin{array}{c}\text { Number } \\
\text { running } \\
\text { inches } \\
\text { per } \\
\text { bundle }\end{array}$ & Application basis & $\begin{array}{l}\text { Maximum } \\
\text { exposure } \\
\text { to weather } \\
\text { (in inches) }\end{array}$ & $\begin{array}{l}\text { Number } \\
\text { bundles } \\
\text { per unit }\end{array}$ & $\begin{array}{l}\text { Number } \\
\text { running } \\
\text { inches } \\
\text { per unit }\end{array}$ \\
\hline $\begin{array}{l}16 \\
18 \\
24 \\
24\end{array}$ & $\begin{array}{l}5 \text { butts, } 2 \\
5 \text { butts, } 21 / 4- \\
4 \text { butts, } 2 \\
\end{array}$ & $\begin{array}{l}20 / 20 \\
18 / 18 \\
13 / 14 \\
13 / 14\end{array}$ & $\begin{array}{l}740 \\
666 \\
499 \\
499\end{array}$ & $\begin{array}{l}\text { Roof square } \\
\text { Sidewall square } \\
\text { Roof square..... }\end{array}$ & $\begin{array}{c}5 \\
51 / 2 \\
10 \\
71 / 2\end{array}$ & $\begin{array}{l}4 \\
4 \\
3 \\
4\end{array}$ & $\begin{array}{l}2,960 \\
2,664 \\
1,497 \\
1,996\end{array}$ \\
\hline
\end{tabular}

In the packing of shingles the number of courses in each end are indicated so that the designation 13/14 means a bundle with 13 courses at one end and 14 courses at the other end, or a total of 27 courses.

Dimension shingles. - Those shingles cut to specified widths and known as dimension shingles shall be designated only according to the number of pieces per bundle.

Running inches.-The chief concern of the shingle buyer is the amount of coverage provided in a bundle of shingles with a prescribed exposure to the weather; this depends on the total width of the shingles when laid side by side, and shall be referred to as "running inches." Modern methods of manufacture and packing have established $181 / 2$ inches as the average measure of running inches in each course of shingles in the bundle and the total running inches 
may be ascertained by multiplying this figure by the number of courses.

Grading tolerance.-The economical production of wood shingles requires the use of high-speed machinery and every other facility to reduce the expense incident to sorting and packing. As a consequence it is possible that some few shingles with unnoticed defects will occasionally find their way into the bundles.

If reinspection is necessitated because of the too frequent appearance of defects, the shipment may be refused in which the total running inches of defective shingles constitutes 4 per cent or more of the shipment.

Inspection.-The inspection of wood shingles, both in car lots at destination or at customary inspection points, shall ordinarily be made on the basis of the usual unit of inspection, which is eight bundles per carload or fraction thereof. Because of the wide variation in shingle widths all percentages shall be calculated on the basis of running inches.

\section{GLOSSARY OF TERMS}

Checks.-A check is a lengthwise separation of the wood, which occurs usually across the rings of annual growth.

Crimps.-A crimp is a breaking down or collapse of wood fibers usually due to an inherent condition in some timber or a result of too rapid drying.

Cross grain.-A condition that should not be confused with the terms "flat" or "edge" grain and that might better be termed "cross fiber," since it is a deviation of the wood fibers from the true parallel of the shingle. It is a serious defect when it runs from one face of the shingle to the other within a longitudinal distance of 4 inches or less in any portion measured 12 inches from the butt.

Decay.-A disintegration of the wood substance caused by the action of wood-destroying fungi. Dote and rot are synonomous with decay.

Diagonal grain.-A condition where the grain of the wood does not run parallel to the edges of the shingle. It is considered a defect when the grain diverges or slants 2 inches or more in width in 12 inches of length.

Feather tips. - A feather tip or shim is a condition of manufacture found on the thin ends of some shingles where the saw came out of the piece prematurely, producing a thin, flimsy featherlike edge. The tip ends of the shingle may be uniformly thin and produce a thoroughly satisfactory roof, but when they are uneven or with corners sawn off, the shingles will not lay up evenly.

Flat grain.-A condition in shingles or lumber where the growth rings are flat or horizontal as opposed to edge-grained or quartered material where the growth rings are on edge or vertical to the surface.

Inots.-A knot is a branch or limb embedded in the wood substance of a tree which has been exposed in the process of manufacture.

Sapwood.-The portion of the wood of a tree immediately next to the bark usually characterized by a lighter color than the "heartwood" or interior wood of the tree. While there is usually no 
difference in the physical strength of the two kinds of wood, sapwood is quite susceptible to decay.

Shakes.-A shake is a lengthwise separation of the wood, which occurs usually between and parallel to the growth rings.

Shims.-See Feather tips.

Square pack.-A unit providing sufficient shingles for the coverage of an area of 100 square feet when the shingles are laid at any specified exposure to the weather. See pages 6 and 7 .

Torn fiber.-This condition may also be referred to as torn graina fuzzy or whiskered appearance usually caused by a dull saw.

Waves.--Irregularities on the face of a shingle also referred to as "washboards" that are usually caused by a wobbling of the saw on its arbor.

Wormholes.-Wormholes are voids in the wood caused by the burrowing action of certain wood-infesting worms.

\section{MANUFACTURERS' RECOMMENDATIONS}

The following information is not part of the commercial standard for western red cedar shingles, but represents the manufacturers' recommendations, based on long experience í from the use of wood shingles: 


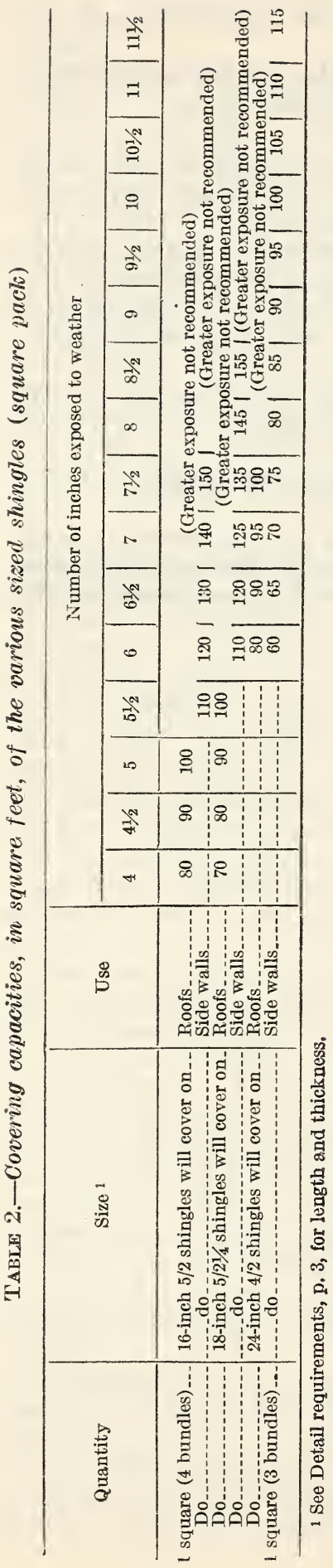


Proper weather exposure.-In roofing, long experience has indicated the wisdom of exposing not more than one-third of the shingle to the weather in order to assure adequate protection from the elements.

Since shingles are commonly manufactured in lengths of 16, 18, and 24 inches and since the grading rules permit 1 inch variation in a portion of the shipment, the maximum weather exposure recommended for a 16-inch $5 / 2$ shingle is 5 inches; for an 18 -inch $5 / 21 / 4$ shingle, $5 \frac{1}{2} / 2$ inches; and for a $2 \pm$-inch $4 / 2$ shingle, $71 / 2$ inches.

For side walls only half the length of the shingle should be exposed to the weather to secure the best results.

Allowing for the variation of lengths the maximum recommended exposure for a 16 -inch shingle is $71 / 2$ inches on the side walls; for an 18 -inch shingle, $81 / 2$ inches; and for a 24 -inch shingle, $111 / 2$ inches.

Formula for covering capacities per "square."-

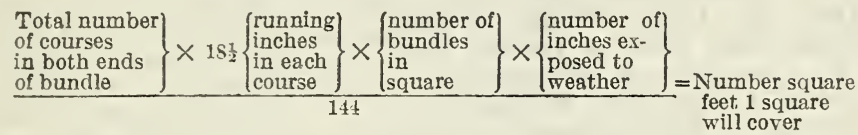

For example.-Find covering capacity of 1 square 16 -inch shingles exposed 5 inches to weather:

$$
\frac{(20+20) \times 18.5 \times 4 \times 5}{144}=\frac{14,800}{144}=102 \text { square feet }
$$

The pioper nail. - The heartwood of western red cedar is naturally highly resistant to decay and when employed as shingles for roofs or: side walls it is desirable to use nails which will last as long as the shingles.

Just as the chain is no stronger than its weakest link, so is a shingled roof no more enduring than its nails.

When ordinary wire nails are used, moisture soon reaches the nail and the process of rusting begins. A small pocket is formed which harbor's moisture and facilities the rusting process. In time the nails become rusted through and the shingles are torn loose under the attack of wind and weather.

If the proper nails are used, however, the shingles will be held securely and give service and protection throughout their natural life.

Numerous experiments have conclusively proved the wisdom and economy of high-grade nails, and maximum service may be assured by using either hot-dipped zinc-coated iron-cut nails or hot-dipped zinc-coated steel-and-copper nails.

TABLE 3.-Nails required per "square" 1

\begin{tabular}{|c|c|c|c|c|}
\hline Size of shingles & $\begin{array}{l}\text { 3d nail, } 11 / 4 \text { inches } \\
\text { long }\end{array}$ & $\begin{array}{c}31 / 2 \mathrm{~d} \text { nail, } 13 / 8 \text { inches } \\
\text { long }\end{array}$ & $\begin{array}{l}\text { 4d nail, } 1 \frac{1}{2} \text { inches } \\
\text { long }\end{array}$ & $\begin{array}{c}5 \mathrm{~d} \text { nail, } 13 / 4 \text { inches } \\
\text { long }\end{array}$ \\
\hline 16 -inch $\ldots \ldots \ldots$ & 3 pounds, 5-inch & $\ldots$ & & \\
\hline 18-inch, $5 / 21 / 4$ thick... & exposure. & 3 pounds, 5-inch & & \\
\hline 24-inch, $4 / 2$ thick & & exposir & 3 pounds, 7 -inch & \\
\hline $\begin{array}{l}\text { Reroofing with wood } \\
\text { shingles. }\end{array}$ & & & & $\begin{array}{l}\text { Amount required de- } \\
\text { pends on size of } \\
\text { shingles used. }\end{array}$ \\
\hline
\end{tabular}

1 Quantities required vary slightly according to distance shingles are exposed to weather. 


\section{GENERAL CONFERENCE}

Pursuant to a request of the Red Cedar Shingle Bureau, a general conference of manufacturers, distributor's, and consumers of red cedar shingles was held at Seattle, Wash.. on March 27, 1931, to consider the adoption of a quality standard. The following were present:

ALEERG, JuLrus, Crescent Logging Co.

ANDERSoN, Aurred, Panama Lumber \& Shingle Co.

Austin, Andy, E. C. Atkins \& Co.

BAILEY, H. J., Saginaw Timber Co.

BaILEY, PHIL, Creo-Dipt Co.

Bergstrom, Georae A., C. B. Iumber \& Shingle Co.

Bevan, Arthur, Red Cedar Shingle Bureau.

BLUNT, J. R., West Coast Lumbermen's Association.

BоттеR, H. H., Washington Surveying \& Rating Bureau.

Braturi, II. J., Bratlie Bros. Miil Co.

Cali, Harry, Red Ceđar Shingle Bureau.

Casw, Alberr, Case Cedar \& Shingle Co.

CASE, N. E., Case Cedar \& Shingle Co.

CHEw, JoskPH, Joseph Chew Shingle Co.

ClakK, Donatd H., Pacific Stained Shingle Co.

CoNverse, J. A., The Timberman.

Craft, Dale, Royal Shingle Co.

Crawrond, P. M., Bureau Foreign and Domestic Commerce, Department of Commerce.

Crosby, W. C., West Coast Lumberman.

Culter, Harold, Hammond Cedar Co.

Edwards, Charles, National Lumber Distributors.

England, Fred A., Fred A. England Lumber Co.

Evenson, Gus, Quality Shingle Co.

Finke, Bos, Blue Ribbon Products Co.

FLUHRER, Lov, Fluhrer Bros.

Fox, E. D., Seattle, Wash.

Frost, TI. D., Edham (Inc.).

GARY, HarRY, New England Manufacturing Co.

GröNDAL, BROR I., University of Washington.

GUILES, DAN, Merrill \& Ring Lumber Co.

Hennesy, Leo, Seattle, Wash.

Hilke, Henry, Seattle Cedar Lumber Manufacturing Co.

Holmes, W. E., Robt. MeNair Shingle Co.

Hogue, C. J., West Coast Lumbermen's Association.

Hubbard, RET $\mathbf{F}$., Eastern Railway \& Lumber Co.

Hughes, A. I., Joseph Chew Shingle Co.

Huling, HarRY, Carbon River Shingle Co.

Huntington, F. B., Huntington Shingle Co.

Huntmagton, Walter, Huntington Shingle Co.

JoLLEY J., Washington \& Oregon Shingle Association.

Jones, Grace, Washington \& Oregon Shingle Association.

Jonis, IRENG, Red Cedar Shingle Bureau.

KIDD, GroRgE, Huntting-Merritt Lumber Co.

KIDD, H. E., Cockfield Brown Co.

luAPLANT, HARLEY, Skagit Mill Co.

LUKE, 'ED., J. E. Pinkham Lumber Co.

MAcKTE, J. E., National Iumber Manufacturers' Association.

Maur, J. S., Mauik-Seattle Lumber Co.

MCEVOY, Jorn, Bloedel-Donovan Lumber Co.

MoNatr, RoBERT, Robert MeNair Shingle Co.

MerriLI, T. D., Merrill-Ring Lumber Co.

IInsx, C. W., Isverett Lumber \& Shingle Co.

Monte, Frap J., Washington \& Oregon Shingle Co.

NAIRN, R. I., Creo-Dipt Co.

Neuberat, Hermati, Neuber' Lumber Co.

Northur, H. I., Seattle, Wash.

O'Connor, J. P., E. C. Atkins \& Co.

Outwer, P. H., Jamison Lumber \& Shingle Co. 
Pauze, Gérge, Polson Lumber \& Shingle Co.

Peterson, Anna, Red Cedar Shingle Bureau.

Putman, C. E., Coast Cedar Shingle Co.

Roles, R. C., Roles Bros. Shingle Co.

Rowe, HarRY, Milwaukee Railway Co.

Schafer, PETER, Schafer Bros.

Schwarz, Jess, Crescent Shingle Co.

Sмiтh, P. R., M. R. Smith Lumber \& Shingle Co.

SnIDER, Hereert L., Snider Shingle Co.

Southard, Jok., Woodlawn Mill Co.

Stemder, HARRY H., Bureau of Standards. Department of Commerce.

Stoltze, Henky, Stoltze Manufacturing Co.

TERry, B. A., John MeMaster Shingle Co.

Truley, FTiEd, Super Shingle Co.

Vaughan, L., Motor Mill Co.

Voget, JoshuA H., Baker, Vogel \& Roush.

Wagner, Corydon, St. Paul \& Tacoma Lumber Co.

WARTES, A. J., Seattle, Wash.

WAsSER, W. M., Wasser Hubbard Co.

Waterman, S. S., St. Paul \& Tacoma Lumber Co.

Weber, Jok, Lake Sammamish Shingle Co.

Weiss, Harry, Crescent Shingle Co.

Whims, Charles A., Great Northern Railway.

WHIn, H. E., Everett, Wash.

WhitTal, VICTOR, Huntting Merritt Lumber \& Shingle Co.

WICKER, W. M., Seattle, Wash.

WoodruFr, GEorge, Cedar Manufacturers' Association.

The conference held under the auspices of the division of trade standards, Bureau of Standards, was presided over by Harry $\mathrm{H}$. Steidle, while Arthur Bevan, of the Red Cedar Shingle Bureau, outlined the desirability of a high-quality standard as a base line of operations for the shingle industry.

The proposed standard was thoroughly discussed, and numerous constructive changes were made. The most progressive step taken was the elimination of the thousand pack for shingles covered by the commercial standard. This action was unanimously supported by the conference and represents a forward step in the settlement of one of the most controversial aspects of the shingle industry.

The general consensus of opinion was decidedly favorable to the adoption of a high standard of quality for the manufacture, sale, and use of red cedar shingles, and upon motion of George Bergstrom, seconded by Dale Craft, it was unanimously voted:

To approve for recommendation to the entire industry the commercial standard of quality proposed by the Red Cedar Shingle Bureau with the adjustments as approved.

To facilitate the procurement of high quality satisfactory shingles, the Red Cedar Shingle Bureau has inaugurated a campaign by which shingles that meet the commercial standard grade may be prominently identified with a quality-guaranteeing label. This label, depicted on page 11, will provide assurance to the buyer since shingles so labeled are guaranteed by the manufacturer as well as the shingle bureau.

\section{STANDING COMMITTEE}

A standing committee was appointed to represent the various interests of the red cedar shingle industry and to receive all comments and suggestions for the improvement of the commercial standard. 
No definite interval was fixed for revision of the standard, but the committee may meet at the call of the chairman when revision appears necessary.

The standing committee approved by the conference consists of the following:

G. A. Bergstrom (chairman), C. B. Lumber \& Shingie Co.

Charles H. Ingram, Weyerhaeuser Timber Co.

RoBert MCNAIR, McNair Shingle Co.

A. J. MoRLeY, Saginaw Timber Co.

J. D. Giles, Creo-Dipt Co.

F. A. HofHeIns, Weatherbest Stained shingle Co.

J. A. EDGECUMBe, Edham Co.

A. E. LANE, Arthur E. Lane Lumber Corporation.

Findury Torrence, Xenia, Ohio.

AL HAGER, National Retail Lumbermen's Association.

W. C. MInLER, Western Retail Lumbermen's Association. Joshua H. Voget, Baker, Vogel \& Roush.

HARRY H. SteIDLE (ex officio secretary), Bureau of Standards.

\section{EFFECTIVE DATE}

The effective date for production and sale of red cedar shingles under the commercial standard was fixed for July 1, 1931.

\section{CERTIFICATION PLAN}

The conference voted its approval of the certification plan for application to red cedar shingles made in accordance with the commercial standard specifications.

The certification plan as applied by the Bureau of Standards to commercial standards consists in the compilation and distribution of lists of manufacturers who are willing, when requested to do so, to certify to purchasers that products supplied by them comply with all the requirements and tests set forth in nationally recognized commercial standards. The plan is also applied to selected Federal specifications.

These lists are available on request to individual consumers, consumer groups, companies, and, in fact, to any prospective purchasers for their guidance.

The benefits now derived from the use of specifications by large consumers are thus made immediately available to the small consumer, with incidental advantage to the larger consumers of convenience in ordering and accepting material with fewer laboratory tests. The manufacturer also benefits from the well-known economies accompanying "mass production."

The lists of manufacturers "willing to certify" to the quality of certain commodities are made by corresponding with, as nearly as possible, all the manufacturers of that product and listing only those who signify their willingness to certify to the purchaser, when requested to do so, that the commodities delivered actually comply with the commercial standard.

Obviously, the purchaser making use of the lists of "willing-tocertify" manufacturers, will select therefrom such manufacturers as are known (or assumed) by him to be reliable.

The trend toward the purchase of materials of certified quality from sources shown on such willing-to-certify lists supplies added 
incentive to standardization on the part of other producers, and thus the benefits of the certification plan will be felt by purchasers either directly or indirectly, whether or not they make use of the plan themselves.

Figure 1 illustrates how an important gioup of producers have arranged to certify complete compliance with the commercial standard. Shingles produced by members of this group to conform to the standard may be readily identified by copies of the following label appearing on each bundle.

\section{COMMERCIAL STANDARDS SERVICE}

Industry has long sensed the need for a wider application and use of specifications developed and approved by nationally recognized

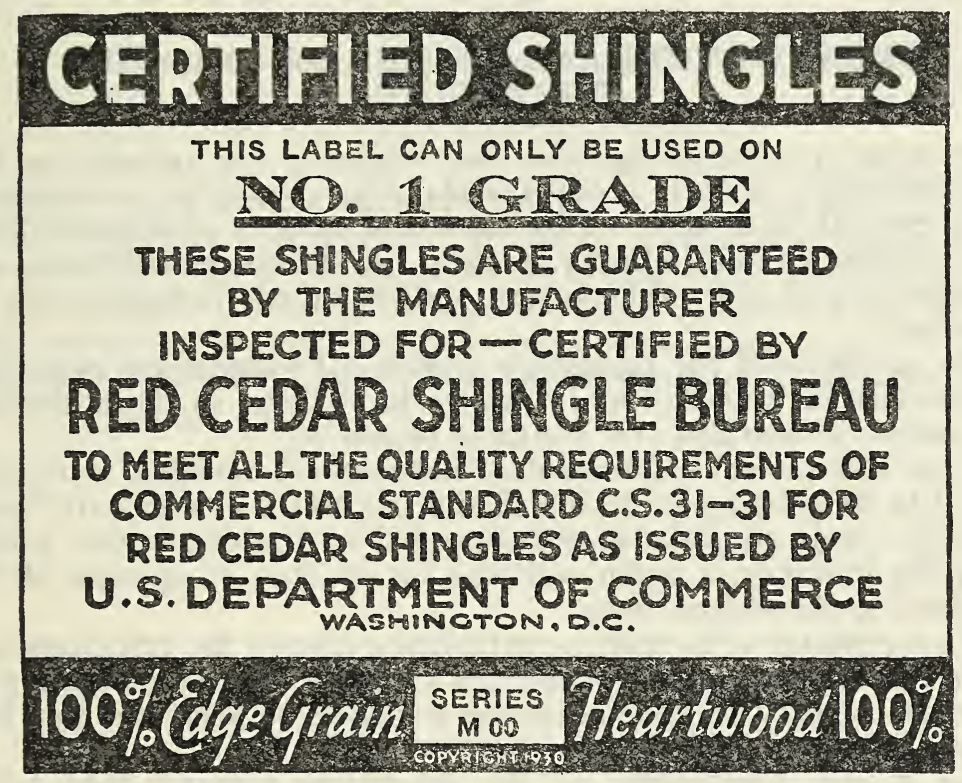

FIGURE 1

organizations. To assist these bodies and the producers and consumers in securing this result and as a natural outgrowth of the movement toward elimination of waste through simplified practice, the Bureau of Standards has set up a procedure under which specifications, properly indorsed, may be printed as official publications of the Department of Commerce and promulgated as "Commercial Standards." This service parallels that of simplified practice in many respects, and is available only upon request.

Broadly speaking, the aim is to continue the same character of cooperative service in this field that is being rendered in simplification. The division of trade standards is not designed to act as a standardizing body, nor will it engage in the preparation of specifications. Its service is mainly promotional in character, since its chief mission is to invite attention to a standard or a specification which 
any branch of industry may want to promulgate on a nation-wide basis; to determine its eligibility for promulgation; to publish and broadcast it in the event the prerequisites of procedure have been met, including a satisfactory majority acceptance; to facilitate the application of the certification plan for the assurance and convenience of the purchaser; to provide means for periodic audits of adherence; and to cooperate with the Bureau of Foreign and Domestic Commerce in determining the desire of industry relative to translation and promulgation of such specifications as a basis for foreign commerce.

In general, it may be said that a simplification covers types. sizes, and varieties of a commodity which are retained by industry on the basis of demand, whereas a commercial standard establishes definite requirements as to grade, quality, or dimensional tolerances in addition to any limitation of variety desired and accepted by the industry.

\section{ORGANIZATION AND DUTIES OF STANDING COMMITTEE}

In order to carry on the aims and desires of the industry in the standardization of their product, a standing committee is appointed at the general conference. This committee consists of members from each division of the industry, namely, producers, distributors, and consumers, and thus reflects the well-balanced viewpoint of all concerned.

The members of the committee receive all suggestions regarding the commercial standard and consider its revision in the event that such action is desirable and mutually beneficial.

If the commercial standard does not warrant revision, it is reaffirmed in its existing form, but if any important changes are found desirable, their adoption is recommended by the committee, whereupon the industry is again solicited for written acceptance of the standard in its revised form.

The committee is in effect a centralizing agency for criticisms and comments regarding the commercial standard and is charged with the responsibility of recommending revisions to keep the standard abreast with current industrial practice.

The proper functioning of the committee requires that, when necessary, its members be willing to attend meetings held at some central place, although in many cases it will be possible to conduct the work by correspondence.

When any deceptions in reference to the commercial standard are reported to the standing committee, it applies moral suasion or other such corrective measures as seem desirable. The Department of Commerce has no "police power" to compel adherence, therefore, it is incumbent upon the standing committee to do all in its power to encourage all divisions of the industry to follow the provisions of the commercial standard and contribute in every way possible to its general adoption and usefulness.

\section{YOUR COOPERATION}

As a producer, distributor, or consumer of some of the commodities for which commercial standards have already been established, 
you are in a position to avail your relf of the benefits arising from the use of quality standards and irrcidentally to add impetus to this method of eliminating waste.

The first step is a declaration in favor of the standard by recording your intention to adhere, as closely as circumstances will allow, to the standards for those products which you may buy or sell.

The receipt of your signed acceptance will permit the listing of your company in new editions of the commercial standards that you accept.

You will, of course, want to examine any commercial standards before signing a formal acceptance. The Bureau of Standards will, therefore, furnish a copy of any standard under consideration for acceptance. A list of current commercial standards is given on page 3 of cover. The publications may also be secured singly or in quantities at a nominal price from the Government Printing Office. Prices will be furnished upon request.

The acceptance of a commercial standard is an entirely voluntary action and applies to the production, sale, and use of stock items. It is not meant to interfere with the introduction, manufacture, or sale of special sizes and types sometimes required.

Trade associations and individual companies often distribute large numbers of the printed standard for the information and guidance of their members or customers. In such cases it is possible to extend the scope and degree of adherence by urging each recipient to send in an acceptance, bearing in mind that the practical value of any standardization is measured by the observance it receives.

An acceptance form for the commercial standard herein covered is included on page 15 . 



\section{ACCEPTANCE OF COMMERCIAL STANDARD}

Please Sign and Return this Sheet to Division of Trade Standards, Bureau of Standards, Washington, D. C.

\section{Date}

Division of Trade Standards,

BUREaU of Standards, Washington, $D . C$.

Gentlenen: We, the undersigned, do hereby accept the original draft of the Commercial Standard as our standard practice in the

Production $^{1}$ $\left.\begin{array}{l}\text { Distribution }{ }^{1} \\ \text { Use }^{1}\end{array}\right\}$ of red cedar shingles beginning

curing its general adoption.

and will use our best effort in se-

To permit intelligent review of the effectiveness of the commercial standard every year by an accredited committee of all interests, working in cooperation with the Department of Commerce, we plan to supply all data, upon request, which may be necessary for the development of constructive revisions. It is understood that any suggested modifications will be submitted as soon as formulated, and shall not be promulgated until accepted in form similar to this recommendation.

Signature

(Kindly typewrite or print the following lines)

Title

Company

Street address

City and State

We are members of the following associations or other organizations interested in the production, sale, or use of red cedar shingles:

1 Please designate which group you represent by drawing lines through the other two. In the case of related interests, trade papers, colleges, etc., desiring to record their general approval, the words "In principle" should be added after the signature. 


\section{TO THE ACCEPTOR}

In signing the acceptance blank, please bear the following points clearly in mind:

1. Adherence.-The Department of Commerce has no regulatory powers to enforce adherence to the commercial standards. Instead, this waste-elimination program is based on voluntary cooperation and self-government in industry. To make this specific standardization operate as a satisfactory example of self-government, it is highly desirable that it be kept distinct from any plan or method of governmental regulation or control. It will be successful according to the degree to which manufacturers, distributors, and purchasers adhere to its terms and conditions.

2. The industry's responsibility.-The department cooperates only on the request of the industry, and assumes no responsibility for industrial acceptance or adherence. This program was developed by the industry on its own initiative. Its success depends wholly on the active cooperation of those concerned.

3. The acceptor's responsibility.- You are entering into an entirely voluntary arrangement, whereby the members of the industry-the distributors and consumers of the product, and others concernedhope to secure the benefits inherent in commercial standardization. Those responsible for this standard realize that instances may occur in which it will be necessary to supply or purchase items not included therein. The purpose is, however, to secure wider support for nationally recognized standards covering grade, quality, and other characteristics of products. Consumers can make the program a success if, in their purchasing, they will make a definite and conscientious effort to specify in terms of this commercial standard.

4. The department's responsibitity.-The function performed by the Department of Commerce is fourfold: First, to act as a referee to insure adequate consideration of the needs of all interests; second, to supply such assistance and advice in the development of this program as past experience with similar programs may suggest; third, to solicit and record the extent of adoption and adherence to the standard; and fourth, to add all possible prestige to this standardization movement by publication and promulgation if and when it is adopted and accepted by all elements directly concerned. 


\section{COMMERCIAL STANDARDS}

CS No. Item

0-30. The commercial standards service and its value to business.

1-28. Clinical thermometers.

2-30. Mop sticks.

3-28. Stoddard solvent.

4-29. Staple porcelain (all-clay) plumbing fixtures.

5-29. Steel pipe nipples.

6-31. Wrought-iron pipe nipples (first revision).

7-29. Standard weight malleable iron or steel screwed unions.

8-30. Plain and thread plug and ring

9-29. Builders' template hardware.

10-29. Brass pipe nipples.

11-29. Regain of mercerized cotton yarns.

12-29. Domestic and industrial fuel oils.

13-30. Dress patterns.

14-31. Boys' blouses, button-on waists, shirts, and junior shirts.

15-29. Men's pajamas.

16-29. Wall paper.

17-30. Diamond core drill fittings.

18-29. Hickory golf shafts.

19-30. Foundry patterns of wood.

Noт1CE.-Those interested in commercial standards with a view toward accepting them as a basis of everyday practice in their industry may secure copies of the above standards, while the supply lasts, by addressing the Division of Trade Standards, Bureau of Standards, Washington, D. C.
20-30. Staple vitreous china plumbing fixtures.

21-30. Interchangeable ground glass joints.

22-30. Builders' hardware (nontemplate).

23-30. Feldspar.

24-30. Standard screw threads.

26-30. Aromatic red cedar closet lining.

27-30. Plate glass mirrors.

28-32. Cotton fabric tents, tarpaulins and covers.

29-31. Staple seats for water-closet bowls.

30-31. Colors for sanitary ware.

31-31. Red cedar shingles.

32-31. Cotton cloth for rubber and pyroxylin coating (in preparation).

33-32. Knit underwear (exclusive of rayon) (in preparation).

34-31. Bag, case, and strap leather (in preparation).

35-31. Plywood (in preparation)

36-31. Fourdrinier wire cloth (in preparation).

37-31. Steel bone plates and screws (in preparation).
25-30. Special screw threads. 
